\title{
Comparing the Cultures of Romania and The Netherlands: When East Meets West
}

\author{
Peter T. van den Berg ${ }^{1}$
}

Tilburg University, The Netherlands

\begin{abstract}
Romania, a former communist country and a recent member to the European Union, and The Netherlands, one of the oldest EU members with a long history of democracy, were compared on national and organizational culture variables. A total of 1,182 Dutch and Romanian participants completed questionnaires that measured (a) Hofstede's four national culture dimensions of power distance, uncertainty avoidance, individualism, and masculinity, (b) what they perceived currently in their jobs (actual practices) and what they wished for in an ideal job (values) on five dimensions of organizational culture: autonomy, interdepartmental coordination, external orientation, human resource orientation, and improvement orientation, and (c) practices and values for transformational leadership. The results showed that the Netherlands scored higher on individualism, and lower on power distance and masculinity, than did Romania. The Dutch perceived higher levels of how autonomy, interdepartmental coordination, human resource orientation, and improvement orientation is actually practiced in organizations, and lower practices levels for external orientation and transformational leadership than did the Romanian sample. With respect to values, the Dutch scored higher on autonomy and lower on interdepartmental coordination, external orientation, human resource orientation, improvement orientation, and transformational leadership than did the Romanians. The finding that Romanians are lower on most practices and higher on most values suggests that Romanians desire change and that East and West European countries within the EU will grow closer to one another other over time.
\end{abstract}

Keywords: national culture, organisational culture

\section{Résumé}

Roumanie, un ancien pays communiste et un membre récent de l'Union européenne et les PaysBas, l'un des plus anciens membres de l'UE avec une longue histoire de la démocratie, ont été comparés sur les variables de la culture nationale et organisationnelle. Un total de 1.182 participants néerlandais et roumain ont rempli des questionnaires qui ont mesuré (a) les quatre dimensions de la culture nationale de Hofstede - distance de pouvoir, l'incertitude, l'individualisme, et masculinité, (b) ce qu'ils perçoivent actuellement a leur emploi (les pratiques actuelles) et ce qu'ils voulaient dans un travail idéal (valeurs) sur les cinq dimensions de la culture organisationnelle: l'autonomie, la coordination interministérielle, l'orientation externe, I'orientation des ressources humaines, et l'orientation a l'amélioration, et (c) les pratiques et les valeurs de leadership transformationnel. Les résultats montrent que les Pays-Bas scores plus élevés sur l'individualisme, et plus bas sur la distance du pouvoir et de la masculinité, que fait la Roumanie. Les Hollandais perçu des niveaux plus élevés de la façon dont l'orientation autonomie, la coordination interministérielle, l'orientation des ressources humaines, et l'amélioration est effectivement pratiquée dans les organisations, et des niveaux inférieurs pratiques pour l'orientation externe et le leadership transformationnel que l'échantillon roumain. En ce qui concerne les valeurs, les Hollandais scores plus élevés sur l'autonomie et plus bas sur la coordination interministérielle, l'orientation externe, l'orientation des ressources humaines, orientation vers le développement, et que le leadership transformationnel ne les Roumains. La constatation que les Roumains sont plus faibles sur la plupart des pratiques et plus sur la plupart des valeurs suggère la volonté du changement des Roumains et que les pays-Orient et Europe de l'Ouest au sein de l'UE se rapprochent les uns des autres d'autres au fil du temps.

Mots-clés: culture nationale, culture et organisationnelle

\footnotetext{
${ }^{1}$ Adresa de corespondenţă: p.t.vandenberg@uvt.nl
} 


\section{Rezumat}

România, o fostă ţară comunistă şi un membru recent al Uniunii Europene, şi Olanda, unul dintre membrii mai vechi ale UE cu o lungă istorie a democraţiei, au fost comparate la nivelul culturii naţionale şi organizaţionale. Un total de 1182 de participanţi olandezi şi români au completat chestionare care au măsurat (a) cele patru dimensiuni ale culturii naţionale propuse de Hofstede - distanţa de putere, evitarea incertitudinii, individualismul, şi masculinitatea, (b) ceea ce ei percepeau în prezent la locurile lor de muncă (practicile actuale) şi ceea ce doreau pentru un loc de muncă ideal (valori) pe cinci dimensiuni ale culturii organizaţionale: autonomie, coordonare interdepartamentală, orientarea externă, orientarea resurselor umane, orientarea spre îmbunătăţire, şi (c) practicile şi valorile pentru leadership transformaţional. Rezultatele au arătat că pentru Olanda scorurile sunt mai mari pe individualism, şi mai mici pe distanţa de putere şi masculinitate, decât pentru România. Olandezii percep un nivel mai ridicat de autonomie, de coordonare interdepartamentală, de orientare de resurse umane şi de orientare spre îmbunătăţire ca fiind practicat în cadrul organizaţiilor, şi niveluri mai scăzute de practică pentru orientarea externă şi leadershipul transformaţional decât populaţia din Romania. În ceea ce priveşte valorile, olandezii obţin un punctaj mai mare pe autonomie şi mai scăzut pentru coordonare interdepartamentală, orientare externă, orientare de resurse umane, orientare îmbunătăţire, şi leadership transformational decât s-a obţinut pentru populaţia românească. Constatarea că românii au scoruri scăzute pentru practici şi mai mari pe cele mai multe valori sugerează că dorinţa de schimbarea şi faptul că ţările est şi vest-europene în cadrul UE se vor apropia de-a lungul timpului.

\section{Cuvinte cheie: cultură naţională, cultură organizaţională}

The fifth enlargement of the European Union (EU) occurred in 2004. Enlargements are not just about expanding, "It is crucially a matter of cultural transformation from a logic of closure and antagonism to a dynamic of openness and accommodation that unlocks new directions of social and system" (Delanty, 2003). Bulgaria and Romania where excluded from the enlargement in 2004 due to unfavourable conditions such as a lack of security and political instability (Smith, 2004). 'The weak administration and judiciary capabilities, as well as the underperforming economies of the two countries did not correspond with the Union's political and economic views (Spendzharova, 2003). However, circumstances had improved by 2007 and Romania joined the European Union. Romania had modernized its political, economic, and social systems to overcome the harsh consequences of communism. The European Union has become a mixture of different cultures, religions, and backgrounds as more countries have continued to join.

As the EU became multicultural, the cultural values of one member state influenced the cultures of other members. Culture can change through international trade and migration. Whether a culture has been influenced or not has depended on the extent to which its people have been attracted to the influencing culture and on how deeply they have striven to maintain their own identity (Berry, 1980). Now that Romania is no longer communist, its people will have had more freedom to develop their own identity. This contrasts radically with the older generation who grew up during the communist era - an era that left a great influence on those who lived under it. Past cultural heritage and religion have shaped the path of current cultural development (Huntington, 1993; Inglehart \& Baker, 2003).

$$
\text { Large-scale research, such as }
$$

Hofstede's (1980) IBM-study, included participants from older members of the European Union. Unfortunately, Romania was not included. Research, that has studied the culture of Romania, has often used samples that have dated back to communist times or to times before the country joined the European Union. Therefore, the purpose of this research was to compare Romania, one of the newest members of the EU, with one of the oldest members, namely, The Netherlands, on perceptions of national and organizational cultures. The countries have had diametrically opposing histories of governing - The Netherlands has been a democracy for centuries whereas Romania, having been a Russian satellite country, was communist. However, the two countries have been united 
in one European Union in which democratic ideals stand for individualism which stresses human independence, liberty, and the importance of individual self-reliance. Communism has been the opposite of individualism and has stood for a loss of identity, autonomy and entrepreneurship because everything must be shared with the group.

\section{Culture}

Most definitions of culture have referred to culture as a set of shared values, beliefs, and practices. They are reinforced by national laws and governmental policies and are reflected in the way people behave at school, in the family, and on the job. Hofstede and Hofstede (2005) defined culture as the collective programming of the mind which distinguishes the members of one group from another. Schwartz (1999) preferred to define culture as those values that ascribe desirable behaviour in a given context and that help to guide the way, select actions, evaluate people and events, and explain their actions and evaluations. Values represent the implicit and or explicit shared abstract ideas about what is desirable in a society and values are learned early in life and primarily in the family Hofstede and Hofstede (2005). The concept of culture is divided into national culture and organizational culture. Collective programming takes place at the organizational, as well as at the national, level. Organization cultures distinguish the employees of one organization from another just as national cultures distinguish members of one nation from another.

\section{National Culture}

Hofstede and Hofstede (2005) described five dimensions which have helped explain national culture. Power distance is the first dimension of national culture and indicates the relationship between a boss and a subordinate or between the relationships of family members. Oyserman (2006) has suggested that high and low power distance should be tested separately because high power assumes dependence whereas low power assumes independence. Uncertainty avoidance is the second dimension and is concerned with how people cope with uncertainty about the future, and with how to use technology, law, and religion as solutions for coping. Societies high on this dimension prefer structured rather than unstructured situations and clear guidelines for behaviour.

The third dimension is individualism, and it's opposite, collectivism. Schwartz (1990) and Triandis (1995) have proposed that this should be seen as a bi-polar, instead of a continuous, scale. It reflects the way people live together in families or tribes and has many implications for values and behaviour. It refers to the extent to which the identities of members of a given culture are shaped primarily by personal choices, and/or by the achievements of the group to which they belong. The way individualism is seen depends on the culture, but a recent metaanalysis by Oyserman, Coon, and Kemmelmeier (2002) showed that individualism and collectivism are orthogonal. This means that individualism and collectivism, and their effects on psychological processes, must each be tested separately, presumably because both exist to some extent in all societies and influence psychological processes when they are made salient. Masculinity, and its opposite femininity, is the fourth dimension. Values such as competition, success and performance are relatively more prevalent in masculine, than in feminine, cultures. There is more emphasis on values such as warm social relationships, quality of life, and care of the weak in feminine cultures (Hofstede \& Hofstede, 2005). The last of Hofstede's dimensions is long-term versus short-term orientation, which can be seen as a focus on the past vs. the future. High scores on this dimension indicate a dynamic, futureoriented mentality, whereas low scores reflect a more static, tradition-oriented mentality.

\section{Organizational Culture}

There have been numerous definitions of organization culture. Smircich (1983) has defined organizational culture as the social "glue" that holds an organization together. Social ideals, beliefs, and values are shared through culture and appear as myths, rituals, stories, and specialized language. According to Van Oudenhoven (2001) these values, believes, and practices may stem from regional or occupational groups or from common and shared organizational experiences. The strength of an organization culture depends on the level of homogeneity of its members' perceptions and beliefs (Schneider, Salvaggio, \& Subirats, 2002). Other studies have proposed that organization 
culture is based on best practices (Hofstede, Neuijen, Ohayv, \& Sander, 1990). For example the GLOBE study measured the difference between the way things were (actual practices) and the way things should have been (what people really value). People have certain values that are not always reflected in the dayto-day behaviours among employees within the organization (House, 2004).

Van den Berg and Wilderom (2004) reviewed the most important models of organization culture and formulated a set of five dimensions representing the elements of these models. Autonomy is the first dimension and measures the degree to which employees have room to make decisions in their jobs. External orientation is the second dimension and measures how organizations function in their external environment. Interdepartmental coordination, the third dimension, concerns how organizational communication is affected when a company is divided into various functional departments. Human resource orientation, the fourth dimension, concerns how human resources influence organizational performance. Improvement orientation is the last dimension in the model by Van de Berg and Wilderom (2004) and indicates how proactive organizations are in trying to achieve better results. Wilderom and Van den Berg (2010) showed that in a sample of branches from a Dutch bank these organizational-culture dimensions were related to perceived organizational performance.

\section{Leadership}

Leadership is another important aspect of organization culture. Transformational leadership has often been contrasted with transactional leadership. The transactional leader can be defined as one who recognizes the rewards followers desire from their work, and as their performance warrants, attempts to satisfy the current needs of followers. Rewards are given for appropriate levels of effort, and the leader responds to followers' self-interests as long as they achieve results (Bass, 1997). In contrast, transformational leadership is thought to activate motivation and interest from their followers by generating awareness and acceptance. Transformational leaders motivate followers to go beyond their self-interests for the good of the group and/or the organization (Bass, 1997). Bass (1997) has written that transformational leadership is effective for every culture and has claimed that the qualities are universal. However, other researchers have assumed that an ideal leadership style differs across cultures. A leader who succeeded in China might not have done so in another country (Smith \& Peterson, 1988).

\section{Hypotheses}

Romania had one of the worst totalitarian regimes in all of Central and Eastern Europe - until 1989. The regime caused a loss of social identity, autonomy and entrepreneurship (Mungiu-Pippidi, 1999). However, Romania has changed dramatically since it was accepted into the EU. None the less it is expected that some cultural influences have remained and that Romanians will score high on concepts related to collectivism. In contrast, The Netherlands has had a long history of democracy and personal freedoms and will therefore score high on concepts related to individualism. Therefore:

Hypothesis 1: The Dutch are more individualistic than Romanians.

Romanians attach more importance to survival and traditional authority, whereas the Dutch attach more importance to well-being and secular-rational authority (Inglehart, 1997). The fact that Romanians are inclined to accept traditional authority implies greater hierarchy. within an organization, and more power distance between leaders and subordinates. Therefore:

Hypothesis 2: There is more power distance in Romania than in The Netherlands.

As noted above, Romania attaches more importance to traditional authority, which also implies that they respect and obey authority. In contrast, people in The Netherlands are inclined towards rational authority which implies responsibility and openness to discussing subjects (Inglehart, 1997). This can be related to the need for structure in work and interpersonal relations and the tendency to avoid ambiguous situations. Romania puts its trust in traditional aspects whereas people in The Netherlands are open to changes. Therefore:

Hypothesis 3: The Netherlands has less uncertainty avoidance than does Romania. 
According to Inglehart's study (1997), Romanians scored high on hard work, earning money, and the importance of work, which in turn might indicate that Romanians will also score high on success, performance, and competition - in short, masculinity. In contrast, The Netherlands scored high on life satisfaction and the importance of having friends which in turn corresponds to femininity and its corresponding values of warm social relationships, quality of life, and care for the weak. Therefore:

Hypothesis 4: Romanians will score higher on masculinity than will respondents from

\section{The Netherlands}

Inglehart's study (1997) showed that the Dutch scored higher on job satisfaction than did Romanians. This indicates that Romanian practices have not yet caught up with Romanian values. Organizations in communist countries have a strong hierarchy, whereas hierarchies in individualistic countries are less prominent. Autonomy is related to individualism so Dutch employees will probably experience more autonomy than will their Romanian counterparts. Romania has had a centralised economy whereas The Netherlands has had a free market economy. Therefore the Dutch have been more externally oriented and have had a greater orientation towards interdepartmental communication. Human resource orientation has been more important in The Netherlands, because individualist countries also consider their human resources whereas communist countries like Romania have been primarily task focused. Human resource management views employees in terms of their psychological needs and how they fit with their corporate cultures, rather than as interchangeable mechanical parts of a machine. Employees in The Netherlands have scored higher on improvement orientation because individualism dictates being more open-minded, which in turn makes it easier to discuss achieving better results and the need to improve. Therefore:

Hypothesis 5: Dutch employees will experience that their work organizations have more of each of the five dimensions of organizational culture than will their Romanian counterparts: (a) autonomy, (b) external orientation, (c) interdepartmental coordination, (d) human resource orientation, and (e) improvement orientation.

The differences between what employees perceive as actual practices and what they value in an ideal job are expected to be larger in Romania than in The Netherlands because Romania has been a developing economy. The European Union will influence the strategies, bring new ideas, and give examples. The practices in Romania might be 'old-fashioned' and the employees might prefer the organization culture to be different compared to the current situation. Dutch organization culture is already quite close to Dutch values due to a long standing free market economy whilst Romania's economy is still evolving. Therefore:

Hypothesis 6: Romanians would like to see more of the following dimensions in an ideal job compared to their Dutch counterparts: (a) autonomy, (b) external orientation, (c) interdepartmental coordination, (d) human resource orientation, and (e) improvement orientation.

According to Hofstede (1980), a tight social framework characterizes collectivism in which people prefer to belong to an organization and participate in group decisions. Transformational leaders motivate their followers to go beyond their self-interests for the good of the group and/or the organization. Romania has had a longstanding collectivist culture, and there has been a greater willingness to belong to an organization. Therefore, a transformational leader would fit with the Romanian culture. The Dutch have always been individualistic and have had less need to identify with organizations. The Netherlands has also had a free market economy which has stimulated more competition. Performance is expected from employees and they in turn expect rewards for their performance. Therefore:

Hypothesis 7: Romanians (a) perceive and (b) value transformational leadership more than do the Dutch.

\section{The Present Study}

The present study adds to the existing knowledge as follows. The Netherlands and Romania were compared well with respect to their national cultures, existing organizational 
cultures and the prevalence of transformational leadership style. This could be done by using matched Dutch and Romanian samples with a large variety of jobs. Hofstede's (1980) data could not be used to compare the national cultures of these countries, first because the data he used to compare many countries including the Netherlands are nearly 40 years old. Second, Romania was not included in the study and the scores of Romania that are provided on Geert Hofstede's website are not empirical data, but are estimated on the basis of several indicators.

\section{Methods}

\section{Sample}

This study included Dutch and Romanian participants who were matched on as many relevant variables as possible. Although the samples were not necessarily representative of their respective national populations, they were comparable to one another. The sample included a total of 1,182 participants. There were two types of participants: either full-time first and second year university students, or people who were currently employed. The university students in each country completed the survey 20 minutes before the end of class and were told that the survey was voluntary and that their responses were anonymous. Students were told to think of their last job when answering questions about organizational culture. All students who participated in the study did have a part-time job beside their study. The organization sample came from a large multinational bank with branches in the Netherlands as well as in Romania and the sample was stratified by department, job-level, gender, age, and years with the company. The companies were approached by contacting the HR-department by e-mail and telephone. More detailed information was offered during meetings with company personnel and the questionnaires were shared with the companies. In the second meeting, the questionnaires were distributed personally by the researcher and the employees were asked to seal the accompanying blank envelop to protect their privacy.

The Dutch sample included psychology and information technology students and consisted of 561 participants, 333 males and 223 females, with an overall mean age $=23.4$ years, $S D=6.69$ years. Of the 496 full-time students, 308 were psychology students and 183 were information technology students, with an overall mean age $=21.42$ years, $S D=2.73$ years. The stratified organization sample contained 65 participants with mean age $=38.55$ years, $S D=8.58$ years. The Romanian student sample also included psychology and information technology students and consisted of 621 participants, of which 164 were males and 455 were females, with a mean age $=24.53$ years, $S D=6.66$ years. There were 311 psychology students and 182 information technology students, with an overall mean age $=22.37$ years, $S D=4.56$ years. The stratified Romanian organization sample contained 128 participants of which 48 were males and 80 were females, with a mean age $=33.06$ years, $S D=6.80$ years.

\section{Instruments}

National culture. National culture was measured with the 20 item Value Survey Module (Hofstede, 1994). Sample items include: "Most people are trustworthy" and "People who fail in life have only themselves to blame." Response scales were all 5-point Likert type scales. Following the manual, the scale anchors were either, agree/disagree, important/unimportant, or always/never, anchors depending on the type of question being asked. The English questionnaire was translated into Romanian using the backtranslation procedure, whereas a Dutch version was available to the author. To obtain the scores on the 4 dimensions of power distance, uncertainty avoidance, individualism, and masculinity special formulas available from the manual were used. Because of these formulas negative values on the dimensions were possible.

Organizational culture. Organizational culture was measured with the Organization Culture Questionnaire, which was developed by Van den Berg and Wilderom (2004). Each item stem is answered on two different response scales, once in terms of how frequently the respondent perceives the item in their current, or most recent, job; and once again in terms of how much the respondent would desire the item in an ideal job. For example, the item, "How often are mistakes discussed among one another so that everyone can learn from them?" is answered on a scale of 1 (almost never) to 5 (very often) - these are termed practices in this paper. The same item is rephrased as, "How important is it to you that mistakes are discussed among one 
another so that everyone can learn from them?" and is answered on a scale of 1 (very unimportant) to 5 (very important) - these are termed values in this paper. By presenting the items on their ideal job next to the items on their current job the respondents were able to indicate the gap between them. The 34 item scale measures the following dimensions, with the number of items per dimension in parentheses: autonomy (6), interdepartmental coordination (6), external orientation (8), human resource orientation (6), and improvement orientation (8). The order of the items was mixed. The Dutch questionnaire was translated into Romanian using the backtranslation procedure. The reliabilities of the practice/values scales respectively, were as follows; autonomy (.78/.68), interdepartmental coordination (.81/.81), external orientation (.76/.84), human resource orientation (.77/.78), and improvement orientation (.81/.78). The scale reliabilities were also calculated within the two countries separately and were all above .73. Wilderom and Van den Berg (2010) showed that the practice scales of these dimensions were related to perceived organizational performance.

Transformational leadership.

Transformational leadership was measured with a 10-item questionnaire that Van den Berg and Wilderom (2004) derived from the Multifactor Leadership Questionnaire (MLQ) by Bass and Avolio (1989). The 10 items were embedded in, and had the same directions as, the organization culture scale. Thus, the practices and values items for transformational leadership used the same 5-point Likert-scales as did the organizational culture items. The Dutch questionnaire was translated into Romanian using the back-translation procedure. The reliabilities for the practice and value scales were .85 and .83 , respectively. Wilderom and Van den Berg (2010) found that the practice scale of transformational leadership was related to objective and perceived organizational performance.

\section{Results}

To control if the practices and the values measure the same construct in the Netherlands and Romania for each dimension Tucker's phi (Tucker, 1951) was calculated. Tucker's phi is a measure association of factor solutions. According to Van de Vijver and Leung (1997) phi needs to be .90 or higher. All practice and value dimensions reached this criterion, except the values of improvement orientation. The results with respect to this last dimension should be interpreted with caution. This analysis was not applicable to the national culture dimensions because these dimensions can only be used at the national level, while Tucker's phi is based on individual scores.

Correlations among all variables are shown in Table 1 . The correlations between age and gender and the other variables tend to be low indicating that the results cannot be strongly affected by the age and the gender of the participants. The correlations between the individual scores on the national-culture dimensions and the organizational-culture dimensions are low. This might be expected because the first set of dimensions is measures at the country level and the second set are measures at the organization level. Some high correlations were found among practice scales and among value scales.

Table 2 shows the mean scores and F-values of the Dutch and Romanians on Hofstede's dimensions of individualism, power distance, uncertainty avoidance, and masculinity. Because of Hofstede's formulas some mean scores were negative. The Dutch scored significantly higher on the individualism dimension then did the Romanians, therefore hypothesis 1 is supported. Romanians scored significantly higher on power distance than did Dutch respondents, therefore hypothesis 2 is supported. There was no significant difference between the two countries on uncertainty avoidance; therefore hypothesis 3 is not supported. Hypothesis 4 was supported because Romanians viewed their country as being significantly more masculine than their Dutch counterparts. 
Table 1. Correlations among Variables

\begin{tabular}{|c|c|c|c|c|c|c|c|c|c|c|c|c|c|c|c|c|c|c|}
\hline Variables & 1 & 2 & 3 & 4 & 5 & 6 & 7 & 8 & 9 & 10 & 11 & 12 & 13 & 14 & 15 & 16 & 17 & 18 \\
\hline \multicolumn{19}{|l|}{$\begin{array}{l}\text { 1. Country }(0= \\
\text { Neth., } 1=\text { Rom. })\end{array}$} \\
\hline $\begin{array}{l}\text { 2. Gender }(0=\text { male, } \\
1=\text { female })\end{array}$ & $.34^{* *}$ & & & & & & & & & & & & & & & & & \\
\hline 3. Age & $.09^{\pi x}$ & $-.07^{*}$ & & & & & & & & & & & & & & & & \\
\hline 4. Individualism & $-.25^{\pi \pi}$ & $-.11^{\pi \pi}$ & $-.06^{*}$ & & & & & & & & & & & & & & & \\
\hline 5. Power distance & $.40^{\pi x}$ & $.22^{\pi \pi}$ & .04 & $-.11^{\pi \pi}$ & & & & & & & & & & & & & & \\
\hline $\begin{array}{l}\text { 6. Uncertainty } \\
\text { avoidance }\end{array}$ & .03 & $.08^{* *}$ & .03 & .02 & $.14^{* *}$ & & & & & & & & & & & & & \\
\hline 7. Masculinity & $.34^{\pi \times}$ & .01 & .03 & $-.13^{\pi \pi}$ & $.14^{\pi \times}$ & $-.06^{*}$ & & & & & & & & & & & & \\
\hline 8. Autonomy-p & $-.35^{\mathrm{x*}}$ & $-.14^{\pi \pi}$ & .03 & $.12^{\pi *}$ & $-.24^{x \times}$ & -.06 & $-.14^{\pi \pi}$ & & & & & & & & & & & \\
\hline $\begin{array}{l}\text { 9. Interdepartmental } \\
\text { cooperation-p }\end{array}$ & $-.08^{* *}$ & .00 & $.08^{* *}$ & -.05 & $-.10^{* *}$ & -.05 & $-.10^{* *}$ & $.34^{* *}$ & & & & & & & & & & \\
\hline $\begin{array}{l}\text { 10. External } \\
\text { orientation-p }\end{array}$ & $.07^{\star}$ & $.07^{*}$ & $.19^{* *}$ & $-.08^{* *}$ & -.04 & -.04 & .01 & $.29^{* *}$ & $.55^{\star *}$ & & & & & & & & & \\
\hline $\begin{array}{l}\text { 11. Human resource } \\
\text { orientation-p }\end{array}$ & $-.06^{*}$ & .00 & .03 & -.05 & $-.11^{* *}$ & $-.09^{* *}$ & -.04 & $.38^{* *}$ & $.56^{* *}$ & $.62^{* *}$ & & & & & & & & \\
\hline $\begin{array}{l}\text { 12. Improvement } \\
\text { orientation-p }\end{array}$ & $-.08^{* *}$ & .00 & $.12^{* *}$ & .00 & $-.14^{\star *}$ & $-.06^{\star}$ & -.03 & $.58^{* *}$ & $.60^{* *}$ & $.67^{* *}$ & $.70^{* *}$ & & & & & & & \\
\hline 13. Autonomy-v & $-.24^{\pi *}$ & -.01 & .00 & $.19^{\pi x}$ & $-.17^{x \times}$ & -.03 & $-.15^{\pi x}$ & $.33^{\mathrm{xx}}$ & $.07^{*}$ & .04 & $.09^{x \times}$ & $.14^{\pi \times}$ & & & & & & \\
\hline $\begin{array}{l}14 . \\
\text { Interdepartmental } \\
\text { cooperation-v }\end{array}$ & $.27^{* *}$ & $.19^{* *}$ & $.11^{* *}$ & $-.06^{*}$ & $.13^{* *}$ & -.03 & .06 & $-.07^{*}$ & $.18^{* *}$ & $.20^{* \star}$ & $.07^{*}$ & $.10^{* *}$ & $.18^{* *}$ & & & & & \\
\hline $\begin{array}{l}\text { 15. External } \\
\text { orientation-v }\end{array}$ & $.45^{* *}$ & $.21^{* *}$ & $.19^{* *}$ & $-.12^{* *}$ & $.19^{* *}$ & .00 & $.17^{* *}$ & $-.12^{* *}$ & $.10^{* *}$ & $.32^{* *}$ & $.10^{* *}$ & $.14^{* *}$ & $.10^{* *}$ & $.63^{* *}$ & & & & \\
\hline $\begin{array}{l}\text { 16. Human resource } \\
\text { orientation-v }\end{array}$ & $.29^{* *}$ & $.24^{* *}$ & $.09^{* *}$ & -.05 & $.13^{* *}$ & .00 & $.08^{* *}$ & -.05 & $.11^{* *}$ & $.21^{* *}$ & $.15^{* *}$ & $.12^{* *}$ & $.23^{* *}$ & $.67^{* *}$ & $.62^{* *}$ & & & \\
\hline $\begin{array}{l}\text { 17. Improvement } \\
\text { orientation-v }\end{array}$ & $.27^{\star *}$ & $.19^{* *}$ & $.12^{* *}$ & -.03 & $.08^{* *}$ & -.03 & $.06^{*}$ & .04 & $.13^{\star *}$ & $.20^{* *}$ & $.11^{* *}$ & $.22^{* *}$ & $.38^{* *}$ & $.64^{* *}$ & $.66^{* *}$ & $.70^{* *}$ & & \\
\hline $\begin{array}{l}\text { 18. Transformational } \\
\text { leadership-p }\end{array}$ & $.07^{*}$ & .05 & $.15^{\star *}$ & -.04 & $-.06^{*}$ & -.06 & .00 & $.38^{* *}$ & $.56^{* *}$ & $.64^{* *}$ & $.65^{* *}$ & $.71^{* *}$ & $.07^{*}$ & $.18^{* *}$ & $.21^{* *}$ & $.19^{* *}$ & $.22^{* *}$ & \\
\hline $\begin{array}{l}\text { 19. Transformational } \\
\text { leadership-v }\end{array}$ & $.36^{* *}$ & $.21^{* *}$ & $.15^{\star *}$ & $-.10^{* \star}$ & $.15^{* *}$ & .03 & $.13^{* *}$ & $-.09^{* *}$ & $.14^{* *}$ & $.25^{* *}$ & $.13^{* *}$ & $.15^{\star \star}$ & $.17^{* *}$ & $.62^{* *}$ & $.69^{* *}$ & $.67^{* *}$ & $.67^{* \star}$ & $.31^{* *}$ \\
\hline
\end{tabular}

Note. $\mathrm{p}=$ practice and $\mathrm{v}=$ value.

${ }^{*} p<.05 .{ }^{* *} p<.01$.

Table 2. ANOVAs of Perceived National Culture in the Netherlands and Romania

\begin{tabular}{|c|c|c|c|c|c|}
\hline & \multicolumn{2}{|c|}{ Netherlands } & \multicolumn{2}{|c|}{ Romania } & \multirow[b]{2}{*}{$F$} \\
\hline & $M$ & $S D$ & $\bar{M}$ & $S D$ & \\
\hline Individualism & 89.84 & 45.47 & 65.38 & 47.99 & $79.81^{* * *}$ \\
\hline 1. Having time for personal life ${ }^{a}(+)$ & 3.98 & .76 & 3.90 & .82 & 3.51 \\
\hline 2. Good physical working conditions ${ }^{a}(-)$ & 3.82 & .70 & 4.10 & .89 & $35.77^{* * *}$ \\
\hline 3. Having job security ${ }^{a}(-)$ & 3.67 & .80 & 4.06 & .95 & $59.69^{\star \star *}$ \\
\hline 4. Having variety in the job ${ }^{a}(+)$ & 3.94 & .82 & 3.80 & .97 & $6.83^{* *}$ \\
\hline Power distance & -13.99 & 41.89 & 24.16 & 46.27 & $216.83^{* * *}$ \\
\hline 1. A good relationship with your supervisor ${ }^{a}(+)$ & 3.59 & .71 & 4.01 & .94 & $73.94^{* * *}$ \\
\hline 2. Being consulted in supervisor's decisions ${ }^{a}(-)$ & 3.77 & .75 & 3.71 & .92 & 1.71 \\
\hline 3. Subordinates are afraid disagreeing with the boss ${ }^{b}(+)$ & 2.78 & .94 & 3.50 & 1.02 & $159.86^{* * *}$ \\
\hline 4. Having two bosses should be avoided ${ }^{c}(+)$ & 3.15 & 1.04 & 3.31 & 1.06 & $7.29^{* *}$ \\
\hline Uncertainty Avoidance & 32.62 & 58.88 & 36.63 & 61.12 & 1.29 \\
\hline 1. You feel nervous at work ${ }^{d}(+)$ & 2.37 & .71 & 2.71 & .63 & $73.39^{\star * *}$ \\
\hline 2. Good managers don't need to know everything ${ }^{\mathrm{c}}(-)$ & 3.72 & .95 & 2.88 & 1.07 & $201.40^{* * *}$ \\
\hline 3. Competition among employees usually does harm ${ }^{c}(+)$ & 3.08 & .96 & 2.62 & 1.04 & $59.34^{\star * *}$ \\
\hline 4. Organization's rules should not be broken ${ }^{c}(+)$ & 2.93 & 1.02 & 3.02 & 1.01 & 2.66 \\
\hline Masculinity & -8.58 & 94.12 & 57.16 & 88.50 & $151.78^{* * *}$ \\
\hline 1. Working with cooperative people ${ }^{a}(-)$ & 3.97 & .77 & 4.14 & .92 & $11.09^{* *}$ \\
\hline 2. Opportunity for job advancement ${ }^{a}(+)$ & 3.70 & 1.18 & 4.20 & .92 & $67.72^{\star \star *}$ \\
\hline 3. Most people can be trusted ${ }^{\mathrm{C}}(-)$ & 3.21 & .96 & 2.60 & .98 & $116.31^{* * *}$ \\
\hline 4. Failure in life is often one's own fault ${ }^{\mathrm{c}}(+)$ & 2.58 & 1.07 & 3.33 & 1.03 & $151.26^{\star * *}$ \\
\hline
\end{tabular}

Note. (+) and (-) indicate that the item is positively resp. negatively related to the dimension.

1 (not important) to 5 (very important)

b 1 (infrequently) to 5 (very often)

c 1 (disagree) to 5 (agree)

d 1 (never) to 5 (always)

${ }^{* *} p<.01 .{ }^{* * *} p<.001$ 
As mentioned before the dimensions of individualism and power distance may consist of independent subdimensions. Besides, Spector, Cooper, and Sparks (2001) showed that Hofstede's scales have poor internal consistency. Therefore, item level differences between the countries were examined and have been presented in Table 2 including abbreviated item contents. The results on the individualism items show that the Romanian sample scored significantly higher on the following items in the individualism factor: "Good physical work conditions" and "Having job security", while the Dutch sample scored significantly higher on job variety. The Romanians scored significantly higher on most of the power distance items, namely, "Subordinates are afraid disagreeing with the boss", "A good relationship with your supervisor", and "Having two bosses should be avoided."

In contrast with Hofstede's uncertainty avoidance dimension several significant difference were found for the item scores. The mean scores of the uncertainty avoidance items showed that the Romanians scored significantly higher on the item: "You feel nervous at work", whereas the Dutch scored significantly higher on the items: "Managers don't need to know everything" and "Competition among employees does usually harm."

The last item cluster shows that the Romanians scored significantly higher on three of the four masculinity items: "Opportunity for job advancement", "Working with cooperative people", and "Failure in life is often one's own fault." The Dutch reported higher scores on "Most people can be trusted."

Table 3. ANOVAs of Organization Culture and Leadership in the Netherlands and Romania

\begin{tabular}{|c|c|c|c|c|c|c|c|c|c|c|}
\hline & \multicolumn{5}{|c|}{ Practices } & \multicolumn{4}{|c|}{ Values } & \multirow[b]{3}{*}{$F$} \\
\hline & \multicolumn{2}{|c|}{ Netherlands } & \multicolumn{2}{|c|}{ Romania } & \multirow[b]{2}{*}{$F$} & \multicolumn{4}{|c|}{ Netherlands Romania } & \\
\hline & $M$ & $S D$ & $\bar{M}$ & $S D$ & & $M$ & $S D$ & $M$ & $S D$ & \\
\hline Autonomy & 3.08 & .71 & 2.55 & .69 & $163.96^{* \star *}$ & 3.84 & .48 & 3.57 & .54 & $74.92^{* \star *}$ \\
\hline Interdepartmental Coordination & 3.20 & .65 & 3.09 & .73 & $7.36^{\star *}$ & 4.05 & .52 & 4.34 & .51 & $95.96^{* * *}$ \\
\hline External Orientation & 3.07 & .60 & 3.15 & .66 & $5.87^{*}$ & 3.66 & .59 & 4.19 & .47 & $301.44^{* * *}$ \\
\hline Human Resource Orientation & 3.19 & .70 & 3.10 & .74 & $4.68^{*}$ & 4.15 & .48 & 4.43 & .44 & $106.25^{\star * *}$ \\
\hline Improvement Orientation & 3.07 & .62 & 2.96 & .72 & $8.14^{\star *}$ & 3.96 & .45 & 4.22 & .47 & $91.13^{\star * *}$ \\
\hline Transformational Leadership & 3.12 & .60 & 3.20 & .70 & $4.49^{*}$ & 3.78 & .50 & 4.15 & .47 & $167.67^{* * *}$ \\
\hline
\end{tabular}

${ }^{\star} p<.05 .{ }^{* *} p<.01 .{ }^{* * *} p<.001$.

Table 3 shows the results with respect to the practices and the values of the organizational culture dimensions and transformational leadership. The fifth hypothesis posited that the Dutch would score higher on all of the organization culture practices dimensions. The results show that the Dutch scored significantly higher on: autonomy, interdepartmental coordination, human resource orientation, and improvement orientation. In contrast to the expectation, the Romanians perceived their organizations as having more of an external orientation. These results confirmed Hypotheses $5 \mathrm{a}, \mathrm{c}, \mathrm{d}$, and e, but not Hypothesis $5 b$.

The sixth hypothesis with regard to values proposed that the Romanians would score higher on the organizational-culture values than the Dutch - that is, how much of each characteristic they would desire in an ideal job. The mean value scores were significantly higher for the Romanians on interdepartmental coordination, external orientation, human resource orientation, and improvement orientation. In contrast to the expectation, the Dutchmen scored significantly higher on the value of autonomy. Thus, hypotheses $6 b, c, d$, and e were confirmed, but not hypothesis $6 a$

The last hypothesis assumes that Romanians perceive and prefer a transformational leadership style more than the Dutchmen. Accordingly, the Romanians scored significantly higher on the practice and the value scales for transformational leadership, therefore hypotheses $7 a$ and $b$ were confirmed.

Additional analyses of variance were performed using age and gender as covariates to control for the effects of these variables, however, the results were similar and did not change the conclusions.

\section{Discussion}

The present study shows that Romania and the Netherlands differ on several elements of national culture, organizational culture, and leadership style. Romania scores significantly higher on power distance than 
does The Netherlands. This corresponds with the hierarchical structure and the traditional lines of authority that are still practiced in Romania (Inglehart, 1997). The second major difference occurs on masculinity, in which Romania also scores significantly higher. Inglehart's study (1997) reports that Romania has a masculine culture, whereas Hofstede and Hofstede's (2005) data reveals that The Netherlands has a stronger tendency towards femininity and that it emphasizes social relationships. The third difference between the two countries occurs on the individualism dimension, on which the Dutch score higher. These findings are consistent with Romania's long history of collectivism as a communist country. The cultures of the Netherlands and Romania, which represent old and new world EU countries respectively, differ strongly and these differences are in line with the common stereotypes for these two countries. Hofstede and Hofstede (2005) argue that national culture is learned during early education and at home and is therefore deeply ingrained in the mind. This suggests that there is a long way to go before the European Union becomes culturally integrated.

A few unexpected differences occur at the item-level. The Netherlands scores higher on the uncertainty avoidance item stating that"competition among employees usually does harm". This might be influenced by Dutch feminine values which indicate a preference for social relationships and not performance. An item on which The Netherlands score unexpectedly lower is the masculinity item: "Working with cooperative people". This might be explained by the Dutch having an individualistic mind and preferring to work independently.

The Dutch perceive their organizations as having more autonomy, interdepartmental coordination, human resource orientation, and improvement orientation, whereas Romanians perceive more external orientation. The higher scores of the Romanians on external orientation can be explained by their Mediterranean culture which emphasizes extravert behaviour. The results indicate large differences not only in how Romanian and Dutch employees perceive the actual practices in their organizations, but also in what they desire in an ideal job.

Organizational practices can only be changed when employees want to change. The results show that the Romanians score higher on four of the five organizational culture values - that is the ideal job - than do the Dutch, namely, interdepartmental coordination, external orientation, human resources orientation, and improvement orientation. However, the Dutch score higher on the value of autonomy, which might be explained by the high level of individualism in the Netherlands. The Romanians show larger differences between what actual (practices) is and what would be ideal (values) than do the Dutch, which indicates that the Romanians have a stronger desire for change.

The question is how such change can be best achieved and the results concerning perceptions of transformational leadership are important for answering this question. Romanians perceive higher levels of actual transformational leadership practices in their organizations, and also value this style more, than do Dutch employees. Research has shown that transformational leaders can effectively change organizations. Therefore, more transformational leadership within Romanian organizations may be the starting point for culture change. The values are already there and when leaders tap into these values, the practices will follow easily.

The results of this research may help $\mathrm{HR}$ practitioners of multinationals to understand cultural differences between the Netherlands and Romania. This knowledge is important for multinationals that may have branches in both parts of the EU. More and more West-European companies will move parts of their operations to East Europe in the future and will need to cope with the cultural differences. Culture training for representatives and expatriates will no doubt be helpful and should focus on the differences reported in the present study. Selecting personnel based on cultural intelligence may also be an important tool to improve cooperation and to avoid misunderstandings. For selection purposes, cases that highlight the differences between the countries can be developed and administered to applicants. The item-approach of the national differences between the Netherlands and Romania provides more detailed information that can be used for training and selection.

A limitation of the study is that the samples are not representative of the populations of both countries. This is because only students and bank employees were used. However, the aim of the study is not to provide absolute levels of perceived national and organizational cultures, but rather to compare 
the two countries to one another. This is achieved in the current study by matching the samples as well as possible and by statistically controlling for the remaining differences. By the same token, the samples of Hofstede's (1980) study, because only IBM employees participated, also do not indicate absolute levels of national culture. Nevertheless, Hofstede's work still affords a good comparison among countries.

Further research should use more extensive samples that include different types of companies as well as more countries so that results will be more generalizable. In addition, future studies should use a longitudinal design to determine how transformational leadership improves organizational culture practices in East European countries.

\section{References}

Bass, B. M. (1997). Does the transactionaltransformational paradigm transcend organizational and national boundaries? American Psychologist, 52, 130-139.

Bass, B. M., \& Avolio, B. J. (1989). Manual for the Multifactor Leadership Questionnaire. Palo Alto, CA: Consulting Psychologists Press.

Berry, J. W. (1980). Social and cultural change. In H. C. Triandis \& R. W. Brislin (Eds.), Handbook of cross cultural psychology. Boston: Allyn \& Bacon.

Delanty, D. (2003). The making of a post-western Europe: A civilisational analysis. Thesis Eleven, 7, 8-25.

Huntington, S. P. (1993). The clash of civilisation? Foreign Affairs, 7(3), 22-49.

Hofstede, G. (1980). Culture's consequences: International differences in work-related values. Beverly Hills, CA: Sage.

Hofstede, G. (1994). Values Survey Module 1994 manual. Maastricht, Netherlands: University of Limburg.

Hofstede, G., \& Hofstede, G. J. (2005). Cultures and organizations: Software of the mind (Revised and expanded 2nd edition). New York: McGraw-Hill.

Hofstede, G., Neuijen, B., Ohayv, D. D., \& Sanders, G. (1990). Measuring organizational cultures: A qualitative study across twenty cases. Administrative Science Quarterly, 35, 286316.

House, R. J., Hanges, P. J., Javidan, M., Dorfman, P. W., \& Gupta, V. (2004). Culture, leadership and organizations: The GLOBE study of 62 societies. Thousand Oaks, CA: Sage.
Inglehart, R. (1997). Modernization and postmodernization: Cultural, economic, and political change in 43 societies. Princeton, $\mathrm{NJ}$ : Princeton University Press.

Inglehart, R., \& Baker, W. E. (2003). Modernization, cultural change, and the persistence traditional values. In: R. A. Dahl, I. Shapiro \& J. A. Cheibub (Eds.), The Democracy Sourcebook (pp. 169-178). Cambridge: Mit Press.

Mungiu-Pippidi, A. (1999) Romania: from procedural democracy to European integration. In: M. Kaldor \& I. Vejvoda (Eds.), Democratization in Central and Eastern Europe (pp. 135-149). London: Pinter.

Van Oudenhoven, J. P. (2001). Do organizations reflect national cultures? A 10-nation study. International Journal of Intercultural Relations, 25, 89-107.

Oyserman, D. (2006). High power, low power, and equality: Culture beyond individualism and collectivism. Journal of Consumer Psychology, 16, 352-356.

Oyserman, D., Coon, H. M., \& Kemmelmeier, M. (2002). Rethinking Individualism and Collectivism. Psychological Bulletin, 128, 372.

Schneider, B., Salvaggio, A. M., \& Subirats, M. (2002). Climate strength: a new direction for climate research. Journal of Applied Psychology, 87, 220-229.

Schwartz, S. H. (1999). A theory of cultural values and some implications for work. Applied Psychology: An International Review, 48, 2347.

Schwartz , S. H. (1990). Individualism-collectivism: Critique and proposed refinements. Journal of Cross-Cultural Psychology, 21, 139-157.

Smircich, L. (1983). Concepts of culture and organizational analysis. Administrative Science Quarterly, 28, 339-358.

Smith, K. E. (2004). The making of EU foreign policy: The case of Eastern Europe. Hampshire: Palgrave Macmillan.

Smith, P. B., \& Peterson, M. F. (1988). Leadership, organization and culture: An event management model. London: Sage.

Spector, P. E., Cooper, C. L., \& Sparks, K. (2001). An international study of the psychometric properties of the Hofstede Values Survey Module 1994: A comparison of individual and country/province level results. Applied Psychology: An International Review, 50, 269-281.

Spendzharova, A. (2003). Bringing Europe back in? The impact of EU conditionality on Bulgarian and Romanian politics. Southeast European 
Politics, 4(2), 141-156.

Triandis, H. C. (1995). Individualism and collectivism. Boulder, CO: Westview Press.

Van den Berg, P. T., \& Wilderom, C. P. M. (2004). Defining, measuring and comparing organisational cultures. Applied Psychology: An International Review, 52, 571-582.

Van den Vijver, F. J. R., \& Leung, K. (1997). Methods and data analysis for cross-cultural research. Thousand Oaks, CA: Sage.

Wilderom, C. P. M., \& Van den Berg, P. T. (2010, August). Socialized charismatic leadership and organization culture as predictors of firm performance. Paper presented at the Academy of Management Conference, Montreal. 